\title{
Optimizing continuity-of-care opportunities to reduce health risks: shared qualitative perspectives from CJDATS 2 research
}

\author{
Jennifer Pankow ${ }^{1 *}$, Yang Yang ${ }^{2}$, Kevin Knight ${ }^{1}$, Wayne EK Lehman ${ }^{1}$ \\ From 2014 Addiction Health Services Research (AHSR) Conference \\ Boston, MA, USA. 15-17 October 2014
}

Current Texas Christian University (TCU) research focuses on reducing risk for relapse and other healthrelated behaviors associated with HIV, HBV, and HCV. The WaySafe curriculum was developed for prisoners in the last phase of their substance abuse treatment before transitioning back to the community, and was designed to improve decisionmaking and recognizing and planning for risky situations. A critical next step is to shift the setting from incarceration to a community setting with probationers during the high-risk transition period after release from prison or completion of residential or intensive outpatient substance abuse treatment. Literature supports the importance of prevention programs [1] as part of the continuity-of-care for offenders and probationers in addressing some service gaps (in the continuum), which are widely recognized to reduce the likelihood of successful client outcomes [2,3].

The purpose of this presentation is to provide evidence from the recently completed second phase of the Criminal Justice Drug Abuse Treatment Studies (CJDATS 2), with insight from key stakeholders that informs the relevance of continuity-of-care and the significant role that community corrections and community-based healthcare agencies fulfill in transitioning probationers from incarceration to home. These qualitative results come from two protocols conducted as part of CJDATS 2: HIV Services and Treatment Implementation in Corrections (HIV-STIC) and Medication-Assisted Treatment in Community Corrections Environments (MATICCE). The organizational-level findings reflect the opinions and views of criminal justice personnel and health-care

\footnotetext{
* Correspondence: j.pankow@tcu.edu

'Institute of Behavioral Research, Texas Christian University, Fort Worth, TX, 76129, USA

Full list of author information is available at the end of the article
}

providers-agencies in partnership with TCU in HIVSTIC and MATICCE. In CJDATS 2, stakeholders participated in an implementation research initiative, utilizing a change team strategy to identify and implement improvements to service delivery. In both HIV-STIC and MATICCE, the services delivery continuum incorporated elements of prison-based services and transition to community-based services in their respective areas. Qualitative results highlight the important contributions of community correction agencies, their direct contact to probationers, and their ability to facilitate linkages to service providers. Findings are discussed, emphasizing the importance of staff commitment and interorganizational relationships in continuity-of-care from prison to community as essential components to optimizing services to probationers.

\begin{abstract}
Acknowledgements
This study was funded by a grant (\#3U01DA016190-0881) to TCU (Kevin Knight, Principal Investigator) from the National Institute on Drug Abuse, National Institutes of Health (NIDA/NIH), with support from the Center for Substance Abuse Treatment of the Substance Abuse and Mental Health Services Administration, the Centers for Disease Control and Prevention, the National Institute on Alcohol Abuse and Alcoholism (all part of the U.S. Department of Health and Human Services); and from the Bureau of Justice Assistance of the U.S. Department of Justice. The content is solely the responsibility of the authors and does not necessarily represent the official views of the funding agencies.
\end{abstract}

\section{Authors' details}

'Institute of Behavioral Research, Texas Christian University, Fort Worth, TX, 76129, USA. ${ }^{2}$ Department of Psychology, University of Louisiana at Lafayette, Lafayette, LA, 70504, USA.

Published: 20 February 2015

\section{References}

1. Copenhaver MM, Johnson BT, Lee I, Harman JJ, Carey MP, Team S, SHARP Research Team: Behavioral HIV risk reduction among people who inject 
drugs: Meta-analytic evidence of efficacy. J Subst Abuse Treat 2006, 31(2):163-171, doi:10.1016/j.jsat.2006.04.002.

2. Althoff A, Altice F, Zelenev A, Meyer J, Fu J, Brown S, Spaulding A:

Correlates of retention in HIV care after release from jail: Results from a multi-site study. AIDS and Behavior 2013, 17:156-170, doi:10.1007/s10461012-0372-1.

3. Spaulding A, Stephenson B, Macalino G, Ruby W, Clarke JG, Flanigan TP: Human immunodeficiency virus in correctional facilities: A review. Clin Infectious Diseases 2002, 35(3):305-312.

doi:10.1186/1940-0640-10-S1-A46

Cite this article as: Pankow et al.: Optimizing continuity-of-care

opportunities to reduce health risks: shared qualitative perspectives

from CJDATS 2 research. Addiction Science \& Clinical Practice 2015

10(Suppl 1):A46.

Submit your next manuscript to BioMed Central and take full advantage of:

- Convenient online submission

- Thorough peer review

- No space constraints or color figure charges

- Immediate publication on acceptance

- Inclusion in PubMed, CAS, Scopus and Google Scholar

- Research which is freely available for redistribution

Submit your manuscript at www.biomedcentral.com/submit 